IZA DP No. 4450

Happiness and Health Care Coverage

David G. Blanchflower

September 2009 


\title{
Happiness and Health Care Coverage
}

\author{
David G. Blanchflower \\ Dartmouth College, University of Stirling, \\ NBER and IZA
}

\section{Discussion Paper No. 4450 \\ September 2009}

\author{
IZA \\ P.O. Box 7240 \\ 53072 Bonn \\ Germany \\ Phone: +49-228-3894-0 \\ Fax: +49-228-3894-180 \\ E-mail: iza@iza.org
}

Any opinions expressed here are those of the author(s) and not those of IZA. Research published in this series may include views on policy, but the institute itself takes no institutional policy positions.

The Institute for the Study of Labor (IZA) in Bonn is a local and virtual international research center and a place of communication between science, politics and business. IZA is an independent nonprofit organization supported by Deutsche Post Foundation. The center is associated with the University of Bonn and offers a stimulating research environment through its international network, workshops and conferences, data service, project support, research visits and doctoral program. IZA engages in (i) original and internationally competitive research in all fields of labor economics, (ii) development of policy concepts, and (iii) dissemination of research results and concepts to the interested public.

IZA Discussion Papers often represent preliminary work and are circulated to encourage discussion. Citation of such a paper should account for its provisional character. A revised version may be available directly from the author. 
IZA Discussion Paper No. 4450

September 2009

\section{ABSTRACT}

\section{Happiness and Health Care Coverage}

In this paper I examine the characteristics of adults who report on whether they have health care coverage and of people who say that they are unable to see a doctor over the preceding year because of the cost. I make use of a unique data set, the Behavioral Risk Factor Surveillance System, a phone survey undertaken in the United States for the years 20052009. I find evidence that not having the ability to see a doctor because of an inability to pay is a major and substantial source of unhappiness in the United States, even for people with high income.

JEL Classification: $\quad 18$

Keywords: life satisfaction, health care coverage

Corresponding author:

David G. Blanchflower

Department of Economics

6106 Rockefeller Hall

Dartmouth College

Hanover, NH 03755-3514

USA

E-mail: blanchflower@dartmouth.edu 
The debate over health care reform is currently raging in the United States. Of particular concern is the large number of people who do not have access to health insurance. It is of interest then to examine who actually has health care coverage and who does not. I make use of a unique data set, the Behavioral Risk Factor Surveillance System, a phone survey undertaken in the United States for the years 2005-2009. Data are available on nearly one and a half million people.

In this paper I examine the characteristics of adults who report on whether they have health care coverage. The main consequence of not having health care coverage, presumably is that that it leads to worse health outcomes. In particular, that is likely to mean being unable to afford to see a doctor, and most importantly, being unable to obtain needed medical treatments. The data set allows me to examine the characteristics of people who say that they are unable to see a doctor over the preceding year because of the cost. This includes people who have health care coverage. I then go on to examine the impact of a) not having health care coverage and b) not being able to see a doctor because of an inability to pay on various measures of happiness. This includes measures of life satisfaction as well as various measures of mental ill health including stress, depression, hopelessness and problems with emotions. I find evidence that not having the ability to see a doctor because of an inability to pay is a major and substantial source of unhappiness in the United States, even for people with high income.

\section{1) Background on health care coverage and health outcomes}

The background to this is the fact that health outcomes in the United States are poor compared with those in many other countries, on some measures, despite the fact that spending per capita is the highest in any country in the world. ${ }^{1}$ The most recent estimates for 2004 of the amounts spent per capita on health care are set out below in PPP\$US.

$\begin{array}{llll}\text { United States } & \$ 6,096 & \text { France } & \$ 3,040 \\ \text { Luxembourg } & \$ 5,178 & \text { Sweden } & \$ 2,828 \\ \text { Norway } & \$ 4,080 & \text { Denmark } & \$ 2,780 \\ \text { Switzerland } & \$ 4,011 & \text { Ireland } & \$ 2,618 \\ \text { Austria } & \$ 3,418 & \text { United Kingdom } & \$ 2,560 \\ \text { Iceland } & \$ 3,294 & \text { Italy } & \$ 2,414 \\ \text { Canada } & \$ 3,173 & \text { Japan } & \$ 2,293 \\ \text { Germany } & \$ 3,171 & \text { Finland } & \$ 2,203 \\ \text { Belgium } & \$ 3,133 & \text { Greece } & \$ 2,179 \\ \text { Australia } & \$ 3,123 & \text { Spain } & \$ 2,099 \\ \text { Netherlands } & \$ 3,092 & \text { New Zealand } & \$ 2,081\end{array}$

${ }^{1}$ http://hdrstats.undp.org/indicators/\#H 
Despite this high spending per capita the US ranks $25^{\text {th }}$ on life expectancy at birth $^{2}, 30^{\text {th }}$ on infant mortality rates ${ }^{3}$. Interestingly, despite this high expenditure on health care the US ranks $28^{\text {th }}$ on the number of physicians per 100,000 people. ${ }^{4}$ There is evidence, though, that on other measures such as survival rates on various cancers such as prostate, colon, colorectal and breast cancer the US performs much better (Coleman, et al, 2008). The Coleman study found that U.S., Japan, and France recorded the highest survival rates among 31 nations for these four types of cancer. Survival rates varied among the 16 states and six metropolitan areas included in the study. Idaho had the best survival rates for rectal cancer in men and Seattle was highest for rectal cancer in women. Patients in Seattle also had the best survival rates for prostate cancer. For all other cancers studied, patients in Hawaii had the highest survival rates. Patients in New York City had the lowest survival rates for all four cancers except rectal cancer in both men and women. For those, patients in Wyoming had the lowest survival rate.

Of particular note in the United States is the proportion of residents who are not covered by health insurance. The latest numbers available from the Census Bureau, which use data from the Current Population Survey (CPS) are reported in Table 1. In 2007 there were 45.6 million people who had no health insurance coverage. This number has increased sharply over time: in 2008, 46.3 million people, or $15.4 \%$ of the population were not covered, up from $13.7 \%$ in 2000 . Table 2 reports the percentage of persons of all ages who failed to obtain needed medical care due to cost at some time during the preceding year. In 2008 the Centers for Disease Control and Prevention reported that approximately $6.5 \%$ were in this category, up from $4.5 \%$ in 1997.

The most important source of health insurance in the U.S. is private insurance; $80 \%$ of the 202 million insured, or 177.8 million persons, have private health insurance. Within that group, the predominant source of private insurance is employer-provided health insurance. Only $10 \%$ of those with private insurance purchase insurance, or 26.6 million on their own, through direct purchase. A further 83 million get their coverage through government provided health care coverage, primarily Medicaid (39.6 million) or Medicare (41.4 million). As is apparent below the availability of health insurance is

${ }^{2}$ Behind, in order, Japan 82.3; Hong Kong 81.9; Iceland 81.5; Switzerland 81.3; Australia 80.9; Sweden 80.5; Spain 80.5; Canada 80.3; Italy 80.3; Israel 80.3; France 80.2; Norway 79.8; New Zealand 79.8; Austria 79.4; Singapore 79.4; Netherlands 79.2; Germany 79.1; United Kingdom 79; Cyprus 79; Finland 78.9; Greece 78.9; Belgium 78.8; Ireland 78.4; Luxembourg 78.4; and United States 77.9

${ }^{3}$ Behind, in order, Iceland; Norway; Sweden; Japan; Finland; Singapore; Slovenia; Czech Republic; Switzerland; Netherlands; France; Spain; Denmark; Austria; Belgium; Luxembourg; Italy; Germany; Greece; Cyprus; Portugal; Australia; Canada; Ireland; United Kingdom; New Zealand; Israel; South Korea; Malta and the United States.

${ }^{4}$ The ranking of countries by the number of physicians per 100,000 people for the period 2000-2004 was as follows. Belgium (449); Estonia (448); Greece (438); Italy (420); Lithuania (397); Israel (382); Uruguay (365); Iceland (362); Switzerland (361); Czech Republic (351); Portugal (342); Austria (338); France (337); Germany (337); Hungary (333); Spain (330); Sweden (328); Malta (318); Slovakia (318); Finland (316); Netherlands (315); Norway (313); Argentina (301); Latvia (301); Denmark (293); Ireland (279); Luxembourg (266) and the United States (256). 
lower among men than women, lower for minorities than for whites and especially low for Hispanics. Approximately one in three Hispanics have no coverage compared with one in seven whites. ${ }^{5}$

$\begin{array}{ll}\text { Males } & 16.7 \% \\ \text { Females } & 13.9 \% \\ \text { Whites } & 14.3 \% \\ \text { White males } & 15.7 \% \\ \text { White females } & 12.9 \% \\ \text { Non-Hispanic whites } & 10.4 \% \\ \text { Blacks } & 19.2 \% \\ \text { Black males } & 21.0 \% \\ \text { Black females } & 17.6 \% \\ \text { Asians } & 16.1 \% \\ \text { Asian males } & 17.3 \% \\ \text { Asian females } & 15.0 \% \\ \text { Hispanics of any race } & 32.1 \% \\ \text { Hispanics of any race males } & 35.1 \% \\ \text { Hispanics of any race females } & 28.9 \%\end{array}$

Of interest also is the extent to which people are prevented from receiving needed medical care due to cost. The Centre for Disease Control provides such information from the National Health Interview Surveys. The proportion of adults that have been unable to obtain needed treatment has risen from $4.5 \%$ in 1997 to $6.5 \%$ in 2008 . Consistent with the data on health care coverage it is especially high for blacks and Latinos.

Data are also available on the extent of health care coverage in the Behavioral Risk Factor Surveillance System (BRFSS) database. ${ }^{6}$ The BRFSS is a state-based system of health surveys that collects information on health risk behaviors, preventive health practices, and health care access primarily related to chronic disease and injury. For many states, the BRFSS is the only available source of timely, accurate data on healthrelated behaviors. The BRFSS was established in 1984 by the Centers for Disease Control and Prevention (CDC); currently data are collected monthly in all 50 states, the District of Columbia, Puerto Rico, the U.S. Virgin Islands, and Guam. More than 350,000 adults are interviewed each year, making the BRFSS the largest telephone health survey in the world. We have data available to us from the surveys of 2005-2008. Note that the 2008 survey contains approximately 1500 observations from 2009, hence we report estimates for 2009 but these should be treated with caution due to the small sample size.

Respondents in the BRFSS were asked the following question.

\footnotetext{
${ }^{5}$ http://www.census.gov/hhes/www/hlthins/historic/index.html

${ }^{6}$ http://www.cdc.gov/BRFSS/
} 
Question 1. "Do you have any kind of health care coverage, including health insurance, prepaid plans such as HMOs, or government plans such as Medicare?"

As Table 3 shows, in 2008, the most recent survey available, $15.2 \%$ of adults aged 18 and over said they had no health coverage, slightly lower than the $16.1 \%$ in 2005 . The number is very close to the $15.4 \%$ reported in Table 1 above based on the Current Population Survey. As with the data from the CPS, lack of coverage is higher among men than women and higher for minorities than whites and especially prevalent for Hispanics. As is to be expected coverage rises with education and income, and is higher for single people than married, divorced or widowed. Lack of coverage is especially high for the young and those in poor health; the unemployed. Lack of coverage is highest in the Virgin Islands followed by Texas and lowest in Hawaii.

Respondents to the BRFSS were also asked a further question.

Question 2. "Was there a time in the past 12 months when you needed to see a doctor but could not because of cost?"

Means and standard deviations of the responses are also tabulated in Table 3. In 2008 $15.6 \%$ reported in the affirmative, up from $13.6 \%$ in 2005 , despite the increase in health care coverage identified above. Interestingly, $8 \%$ of respondents with health care coverage said they couldn't see a doctor because of the cost. Presumably this arose because of large deductibles or because of restrictions of access to doctors of choice through HMOs,

Prevalence was higher for females than males, as was found in Table 2 for inability to obtain treatment for needed medical care. Those aged 20-25, were especially impacted, as were minorities, those with little schooling, those on low incomes, the separated, the unemployed, the disabled. Incidence was highest in Texas and lowest in Hawaii.

Figure 1 plots average health status against the proportion that say they are unable to see a doctor because of the cost. The unit of observation is the state, averaged across all years. There is a strong negative correlation $\left(\mathrm{R}^{2}=.40\right)$. Figure 2 plots the proportion who cannot afford a doctor against fetal mortality rates for $2005 .^{7}$ There is a positive relationship $\left(\mathrm{R}^{2}=.28\right)$. There is only a weak positive relationship in Figure 3 with suicide rates, that is, intentional self-harm, for $2005\left(\mathrm{R}^{2}=.10\right)$. States with high proportions of individuals, who are unable to afford to see a doctor, unsurprisingly, have poor health outcomes. Inability to afford to see a doctor is negatively correlated with good health outcomes.

\section{2) Econometric analysis of the incidence of health care coverage}

\footnotetext{
${ }^{7}$ Source: M.F. MacDorman and S. Kirmeyer (2009), 'Fetal and Perinatal Mortality, United States, 2005', National Vital Statistics Reports, Volume 57, Number 8 January 28. http://www.cdc.gov/nchs/data/nvsr/nvsr57/nvsr57 08.pdf
} 
In Table 4 I estimate a set of dprobit equations using STATA where the probability of not having health coverage is modeled. ${ }^{8}$ This is equivalent to estimating the ceteris paribus effects, that is the effects holding other factors constant i.e. they are partial derivatives. The question to be answered then is whether the effects identified in the raw data remain once controls are included for income and schooling and whether the respondent is working, for example. In column 1 I only include controls for age, gender, race, year and state of residence. Controls are added for schooling, marital status, labor force status, income, Body Mass Index (BMI), size of household in column 2. The log of the state unemployment rate, measured by month, year and state is added in column 3 . The probability of not having coverage in column 2 , once these controls are included:

a) follows an inverse U-shape in age maximizing at age 32.5 ,

b) and is higher for Hispanics, Native Americans, men, the self-employed, the unemployed, the least educated, those with low incomes, with a low BMI and those living in Texas.

Rather surprisingly the unemployment rate is significant and negative in column 3. Data are unavailable on unemployment rates for Guam and the Virgin Islands, hence the smaller sample size.

Table 5 performs a similar exercise but now the dependent variable is the inability to afford to see a doctor. Results are similar. In column 2 with controls the probability of not being able to see a doctor

a) also follows an inverted U-shape in age maximizing at age 32 .

b) is higher for females, minorities, in 2008 and 2009, in Texas, among the least educated, the unemployed, with high BMIs, in larger households and those on low incomes.

c) the log of the state unemployment rate is insignificant for people age 65 and older but is significant and positive for those under the age of 65 (column 4) and overall (column $5)$.

\section{3) Happiness and mental health}

In this section I examine the extent to which the lack of availability of health care coverage and/or the inability to see a doctor impacts an individual's well-being.

\footnotetext{
${ }^{8}$ dprobit fits maximum-likelihood probit models and is an alternative to probit. Rather than reporting the coefficients, dprobit reports the marginal effect, that is the change in the probability for an infinitesimal change in each independent, continuous variable and, by default, reports the discrete change in the probability for dummy variables.
} 
Data on happiness and well-being are available in many surveys around the world. There is even a World Database of Happiness. ${ }^{9}$ Most surveys now use a common format for the questions. These are typically asked as follows.

Question 3. 3-step happiness - e.g. from the US General Social Survey (GSS)

"Taken all together, how would you say things are these days - would you say that you are very happy, pretty happy or not too happy?"

Question 4. 4-step life satisfaction - e.g. from the European Eurobarometer Surveys

"On the whole, are you very satisfied, fairly satisfied, not very satisfied, or not at all satisfied with the life you lead?"

Answers to happiness and life satisfaction questions, it turns out, are well correlated with a number of important factors (for references see Di Tella and MacCulloch, 2007).

1. Objective characteristics such as unemployment.

2. Assessments of the person's happiness by friends and family members.

3. Assessments of the person's happiness by his or her spouse.

4. Heart rate and blood-pressure measures of response to stress.

5. The risk of coronary heart disease

6. Duration of authentic or so-called Duchenne smiles. A Duchenne smile occurs when both the zygomatic major and obicularus orus facial muscles fire, and human beings identify these as 'genuine' smiles (see Ekman, Friesen and O'Sullivan (1988) and Ekman, Davidson and Friesen, (1990)).

7. Skin-resistance measures of response to stress.

8. Electroencephelogram measures of prefrontal brain activity.

The main, ceteris paribus, findings from happiness and life satisfaction equations across countries and time are as follows (Blanchflower, 2009; Blanchflower and Oswald, 2004a, 2004b, 2008, 2009; Winkelmann and Winkelmann, 1998).

\section{Well-being is higher among:}

Women

Married people

The highly educated

Active involvement in religion

\footnotetext{
${ }^{9}$ See http://www1.eur.nl/fsw/happiness/
} 
The healthy

Those with high income

The young and the old - U-shaped in age

The self-employed

People with low blood pressure

The sexually active and especially those who have sex at least once a week

Those with one sex partner

Those without children

Well-being is lower among:

Newly divorced and separated people

Adults in their mid to late $40 \mathrm{~s}$

The unemployed

Immigrants and minorities

Those in poor health

Commuters

People with high blood pressure

The less educated

The poor

The sexually inactive

Those with children

There have been a number of recent surveys of the happiness literature including Clark et al (2007); Frey and Stutzer (2002a, b) and Di Tella and MacCulloch (2006) which provide discussions of the relevant issues. Recent findings from the statistical happiness research include the following:

(i) For a person, money does buy a reasonable amount of happiness. But it is useful to keep this in perspective. Very loosely, for the typical individual, a doubling of salary makes a lot less difference than life events like marriage or unemployment.

(ii) For a nation, things are different. Whole countries, at least in the West where almost all the research has been done, do not seem to get much happier as they get richer.

(iii) Happiness is U-shaped in age. Women report higher well-being than men. Two of the biggest negatives in life are unemployment and divorce. Education is associated with high reported levels of happiness even after controlling for income.

(iv) Happy people are less likely to commit suicide (Koivuma et al, 2001).

(v) The structure of a happiness equation has the same general form in each industrialized country (and possibly in developing nations, though only a small amount of evidence has so far been collected). In other words, the broad statistical patterns look the same in France, Britain and the United States. As Di Tella and MacCulloch note "well-being equations, (where happiness and life satisfaction scores are correlated with the 
demographic characteristics of the respondents) are broadly "similar" across countries, (is) an unlikely outcome if the data contained just noise" (2007, p.9).

(vi) There is some evidence, that the same is true in panels of people (that is, in longitudinal data). Particularly useful evidence comes from looking at windfalls, like lottery wins.

(vii) There is adaptation. Good and bad life events wear off, at least partially, as people get used to them.

(vii) Relative things matter a great deal. First, in experiments, people care about how they are treated compared to those who are like them, and in the laboratory will even pay to hurt others to restore what they see as fairness. Second, in large statistical studies, reported well-being depends on a person's wage relative to an average or 'comparison' wage including Blanchflower and Oswald (2004); Di Tella et al (2005) and Luttmer (2005). Third, wage inequality depresses reported happiness in a region or nation (controlling for many variables), but the effect is not large (Alesina et al, 2004). Some of these patterns are visible in raw data alone. Strong correlations with income, marriage and unemployment are noticeable.

Since 2005 the BRFSS surveys have included data on life satisfaction. These BRFSS happiness data have already been examined by Oswald and $\mathrm{Wu}$ (2009). The question asked is slightly different from that used in the Eurobarometer surveys identified above. The question asked was

Question 5. In general, how satisfied are you with your life? - very dissatisfied, dissatisfied, satisfied or very satisfied?

Weighted responses were as follows (\%).

2005

2006

2007

2008

2005-2009

$\begin{array}{cc}\text { very dissatisfied } & \text { dissatisfied } \\ 0 & 5 \\ 0 & 4 \\ 1 & 4 \\ 1 & 4 \\ 1 & 4\end{array}$

satisfied 50

50

50

49

50 very satisfied
45

46

44

45

45
$\mathrm{N}$

356,612

363,425

372,019

380,855

$1,473,902$

As has been widely found in the happiness literature, most people report being satisfied or very satisfied with their lives. Patterns of responses also vary little over time. The availability of these data files allows us to firstly show the main determinants of life satisfaction and then examine the impact of the lack of health care coverage and inability to see a doctor. Table 6 estimates ordered logits with $1=$ very dissatisfied....4=very satisfied, hence positive coefficients illustrate higher levels of satisfaction. Column 1 includes a dummy for the inability to see a doctor, column 2 adds a dummy if the respondent has no health care, which is insignificant. In column 3 the inability to see a doctor dummy is excluded. Column 4 re-estimates the equation in column 1 using 
Ordinary Least Squares (OLS). Life satisfaction is U-shaped in age, minimizing at age 44 (Blanchflower and Oswald, 2008, 2009). It is higher among minorities than it is among whites once income and schooling are controlled for.

Life satisfaction is negatively correlated with BMI (Blanchflower, Oswald and Van Landeghem, 2009). It is higher for women than men (Blanchflower and Oswald, 2004). Happiness is positively correlated with education and income, is higher for the employed than the unemployed or the disabled, is higher for married people than for singles or those who are divorced, separated or widowed. Happiness rises with the size of household. Non-smokers are happier than smokers. Those who do exercise are happier. Children lower happiness. Indeed, people with no children are happiest; as the number of children rises then happiness falls.

When a dummy for not being able to see a doctor is included it is always significant, whether or not a dummy for lack of health insurance is included. When the two variables are included together, the lack of insurance variable is insignificant. The inability to see a doctor is highly significant, with a t-statistic of over 100 even when a full set of controls are included for income, labor status, smoking, exercise and BMI etc.. Column 4 allows us to determine the size of this effect. It re-estimates the equation in column 1 but now using Ordinary Least Squares. Little of substance is altered. The size of the coefficient on the, couldn't afford a doctor, dummy is -.212 . This is only slightly smaller in size than the coefficient of the dummy on the $>=\$ 75,000$ income variable. The effect is large, even when income is controlled for.

To explore this issue further Table 7 estimates a series of ordered logits by income group. The effect of not seeing a doctor is significant in each of the equations. Particularly impressive is the fact that this is the case even for those in the highest income category (column 4), even if they are in very good or excellent health. The effects are broadly of the same orders of magnitude. ${ }^{10}$ It is of comparable magnitude to being unemployed for at least twelve months.

Not having the ability to see a doctor because of an inability to pay is a major and substantial source of unhappiness in the United States, even for people with high income.

In addition to the question on life satisfaction, respondents were asked three further questions on their mental health.

Question 6. Now thinking about your mental health, which includes stress, depression, and problems with emotions, for how many days during the past 30 days was your mental health not good?

\footnotetext{
${ }^{10}$ When the equations in Table 7 were re-estimated by OLS the coefficients on the couldn't afford a doctor were as follows, with t-statistics in parentheses - $<\$ 20 \mathrm{k}=-.208$ (64.0); $\$ 20 \mathrm{k} \&<\$ 50 \mathrm{k}=-.205$ (81.9); \$50k \& $<\$ 75 \mathrm{k}=-.210(42.4) ; \$ 75 \mathrm{k}=-.221(40.9)$ and $\$ 75 \mathrm{k}$ and healthy $=-.182(26.9)$.
} 
Question 7. During the past 30 days, about how often did you feel so depressed that nothing could cheer you up? - All, most, some, a little, or none of the time?

Question 8. Over the last 2 weeks, how many days have you felt down, depressed or hopeless?

Question 6 is available in all years of the survey. Two thirds of respondents reported zero days. $^{11}$ An OLS equation with the number of days when mental health is poor is reported in column 1 Table 8 . Not being able to afford a doctor increases the number of days by three when mental health was reported as not good.

Question 7 is available only in the 2007 survey and in only 24 states. This question was used on a selective basis state by state. Weighted responses were as follows; none of the time $81.5 \%$; a little of the time $10 \%$; some of the time $6 \%$; most of the time $1.5 \%$ and all of the time $1 \%$. Again lack of access to a doctor adds to the probability of an individual being depressed.

Question 8 is available from 2005-2009 with the majority of responses from 2006 and is available for 39 states and Puerto Rico. ${ }^{12}$ Not being able to afford a doctor raises the number of days feeling 'down, depressed and hopeless' by over one day.

A poor mental health equation such as the ones in Table 8 look much like the inverse of the life satisfaction equations in Tables 6 and 7, for example.

There is strong evidence that inability to see a doctor because of the cost not only has a large and significant effect lowering life satisfaction it also worsens mental health.

\section{4) Interpretation and Conclusion}

The evidence presented in this paper suggests that not being able to see a doctor due to inability to pay has very large effects on well-being. But, is the size of the effects plausible, given that they seem so large. For example, in Table 6 the size of the coefficient of -.21 is approximately the same as the difference between zero income and income of $\$ 75,000$ or more or between working as an employee and having been unemployed for at least twelve months.

These effects are larger than the effects from the equivalent amount of money that the service would cost, because the person could simply pay for them. But that is to be expected as what is being picked up is not the cost of the coverage itself but the cost of the service needed. So health insurance, say costs $\$ 10,000$ a year but if an individual falls ill, the cost could be half a million dollars. Hence the need for insurance.

\footnotetext{
${ }^{11}$ The distribution of days of poor mental health is as follows: 0 days $=66 \% ; 1$ day $=4 \% ; 2$ days $=6 \% ; 3$ days $=3 \%$; 4 days $=2 \% ; 5-9$ days $=6 \% ; 10-19$ days $=6 \% ; 20+$ days $=6 \%$.

12 The weighted distribution was as follows 0 days $71 \% ; 1$ day $8 \% ; 2$ days $7 \% ; 3$ days $3 \% ; 4$ days $2 \% ; 5$ days $2 \%$; 6 days $0 \%$; 7 days $2 \%$; $8-13$ days $2 \%$ and 14 days $3 \%$.
} 
They, or a member of their family, have just experienced a negative health shock. The uncertainty around subsequent health care expenses could be causing this big fall in happiness. By falling ill, the person who needs the treatment experienced a major negative income and wealth shock. Not having access to a doctor lowers life satisfaction and worsens mental health. And by a lot, even controlling for income, education and many other controls. This is true even for people with high incomes. Hence, providing health care coverage for all will likely raise the health and happiness of the nation. 


\section{References}

Alesina, A, R., Di Tella and R.J. MacCulloch (2004), 'Inequality and happiness: are Europeans and Americans different?', Journal of Public Economics, 88, pp. 2009-2042.

Blanchflower, D.G., and A.J. Oswald (2004a), 'Well-being over time in Britain and the USA. Journal of Public Economics, 88, pp. 1359-1386.

Blanchflower, D.G., and A.J. Oswald (2004b), 'Money, sex and happiness', $\underline{\text { Scandinavian }}$ Journal of Economics, 106(3), pp. 393-415.

Blanchflower, D.G., and A.J. Oswald (2008), 'Is Well-being U-shaped over the life cycle?', Social Science and Medicine, 66(6), pp. 1733-1749.

Blanchflower, D.G., and A.J. Oswald (2008), 'The U-shape without controls: a response to Glenn', Social Science and Medicine, 69(4), pp. 486-488.

Blanchflower, D.G., A.J. Oswald and B. Van Landeghem (2009), 'Imitative obesity and relative utility', Journal of the European Economic Association, 7:2/3, April, pp. 528-538.

Clark, A.E., P. Frijters and M. Shields (2007), 'Relative income, happiness and utility: an explanation for the Easterlin paradox and other puzzles', Journal of Economic Literature, (forthcoming).

Clark, A.E., and A.J. Oswald (1994), 'Unhappiness and unemployment', Economic Journal, 104, pp. 648-659.

Coleman, M.P. et al (2008), 'Cancer survival in five continents: a worldwide populationbased study (CONCORD)', The Lancet Oncology, Volume 9, Issue 8, pp. 730 - 756, August.

Di Tella R. and R.J. MacCulloch (2006), 'Some uses of happiness data in economics', Journal of Economic Perspectives, 20(1), Winter, pp. 25-46.

Di Tella R. and R.J. MacCulloch (2007), 'Happiness, contentment and other emotions for central banks', NBER Working Paper \#13622.

Ekman, P., R. Davidson and W. Friesen (1990), 'The Duchenne smile: emotional expression and brain physiology II', Journal of Personality and Social Psychology, 58(2), pp. 342-53.

Ekman, P., W. Friesen and M. O'Sullivan (1988), 'Smiles when lying', Journal of Personality and Social Psychology. 54(3), pp. 414-20.

Frey, B. S. and A. Stutzer (2002a), Happiness and economics, Princeton and Oxford: Princeton University Press. 
Frey B.S. and A. Stutzer (2002b), 'What can economists learn from happiness research?', Journal of Economic Literature, 40(2), June, pp. 402-435.

Gruber, J. (2008), 'Covering the uninsured in the United States', Journal of Economic Literature, 46(3), September, pp. 571-606

Koivuma, H.H., R. Honkanen, H. Viinamaeki, K. Heikkalae, J. Kaprio and M. Koskenvuo (2001), 'Life satisfaction and suicide; a 20-year follow-up study', American Journal of Psychiatry, 1589(3), pp. 433-439.

Luttmer, E. (2005), 'Neighbors as negatives; relative earnings and well-being', Quarterly Journal of Economics, August, 120(3), pp. 963-1002.

Oswald, A.J. and S. Wu (2009), 'Well-being across America: Evidence from a random sample of one million U.S. citizens', unpublished paper, Warwick University and Hamilton College.

Winkelmann, L., and R. Winkelmann (1998), 'Why are the unemployed so unhappy? Evidence from panel data', Economica, 65, pp. 1-15. 
Table 1. Health Insurance Coverage Status and Type of Coverage by Sex, Race and Hispanic Origin: 1999 to 2008

\begin{tabular}{|c|c|c|c|c|c|c|c|c|c|c|}
\hline \multirow[b]{3}{*}{ Year } & \multirow{3}{*}{$\begin{array}{l}\text { Total } \\
\text { People }\end{array}$} & \multicolumn{8}{|c|}{ Covered by Private or Government Health Insurance } & \multirow{3}{*}{$\begin{array}{c}\text { Not } \\
\text { Covered }\end{array}$} \\
\hline & & \multirow[b]{2}{*}{ Total } & \multicolumn{3}{|c|}{ Private Health Insurance } & \multicolumn{4}{|c|}{ Government Health Insurance } & \\
\hline & & & Total & $\begin{array}{l}\text { Employment- } \\
\text { based }\end{array}$ & $\begin{array}{c}\text { Direct } \\
\text { Purchase }\end{array}$ & Total & Medicaid & Medicare & $\begin{array}{c}\text { Military } \\
\text { Health } \\
\text { Care 1/ }\end{array}$ & \\
\hline 2008 & 301,483 & 255,143 & 200,992 & 176,332 & 26,777 & 87,411 & 42,641 & 43,029 & 11,560 & 46,340 \\
\hline 2007 & 299,106 & 253,449 & 201,991 & 177,446 & 26,673 & 83,031 & 39,554 & 41,375 & 10,955 & 45,657 \\
\hline 2006 & 296,824 & 249,829 & 201,690 & 177,152 & 27,066 & 80,270 & 38,281 & 40,343 & 10,547 & 46,995 \\
\hline 2003 & 288,280 & 244,876 & 199,871 & 175,844 & 26,783 & 76,755 & 35,647 & 39,456 & 9,979 & 43,404 \\
\hline 2002 & 285,933 & 243,914 & 200,891 & 177,095 & 26,846 & 73,624 & 33,246 & 38,448 & 10,063 & 42,019 \\
\hline 2001 & 282,082 & 242,322 & 201,695 & 178,261 & 26,309 & 71,295 & 31,601 & 38,043 & 9,552 & 39,760 \\
\hline 2000 & 279,517 & 241,091 & 202,794 & 179,436 & 26,799 & 69,037 & 29,533 & 37,740 & 9,099 & 38,426 \\
\hline 1999 & 276,804 & 238,037 & 200,721 & 176,838 & 27,731 & 67,683 & 28,506 & 36,923 & 8,648 & 38,767 \\
\hline 2005 & 100.0 & 84.7 & 68.5 & 60.2 & 9.2 & 27.3 & 13.0 & 13.7 & 3.8 & 15.3 \\
\hline 2004 & 100.0 & 85.1 & 69.0 & 60.5 & 9.5 & 27.3 & 13.0 & 13.6 & 3.7 & 14.9 \\
\hline 2003 & 100.0 & 84.9 & 69.3 & 61.0 & 9.3 & 26.6 & 12.4 & 13.7 & 3.5 & 15.1 \\
\hline 2002 & 100.0 & 85.3 & 70.3 & 61.9 & 9.4 & 25.7 & 11.6 & 13.4 & 3.5 & 14.7 \\
\hline 2001 & 100.0 & 85.9 & 71.5 & 63.2 & 9.3 & 25.3 & 11.2 & 13.5 & 3.4 & 14.1 \\
\hline 2000 & 100.0 & 86.3 & 72.6 & 64.2 & 9.6 & 24.7 & 10.6 & 13.5 & 3.3 & 13.7 \\
\hline 1999 & 100.0 & 86.0 & 72.5 & 63.9 & 10.0 & 24.5 & 10.3 & 13.3 & 3.1 & 14.0 \\
\hline
\end{tabular}

Source: Current Population Survey - http:/www.census.gov/hhes/www/hlthins/historic/index.html 
Table 2. Percentage of persons of all ages who failed to obtain needed medical care due to cost at some time during the past 12 months: United States, 1997-2008

$\begin{array}{ll}2008 & 6.5 \\ 2007 & 5.8 \\ 2006 & 5.8 \\ 2005 & 5.3 \\ 2004 & 5.5 \\ 2003 & 5.3 \\ 2002 & 4.7 \\ 2001 & 4.7 \\ 2000 & 4.5 \\ 1999 & 4.3 \\ 1998 & 4.2 \\ 1997 & 4.5 \\ & \\ \text { Under 18 years, total } & 2.8 \\ 18-64 \text { years, total } & 8.8 \\ 65 \text { years and over, total } & 2.4 \\ \text { All ages } & 6.5 \\ \text { Males } & 5.9 \\ \text { Females } & 7.1 \\ & \\ \text { Hispanic or Latino } & 7.7 \\ \text { Not Hispanic or Latino, single race, white } & 6.0 \\ \text { Not Hispanic or Latino, single race, black } & 8.3\end{array}$

Source: http://www.cdc.gov/nchs/nhis/released200906.htm\#1 
Table 3. Means and standard deviations for the proportion without health care coverage and those who didn't see a doctor because of the cost, averages 2005-2009.

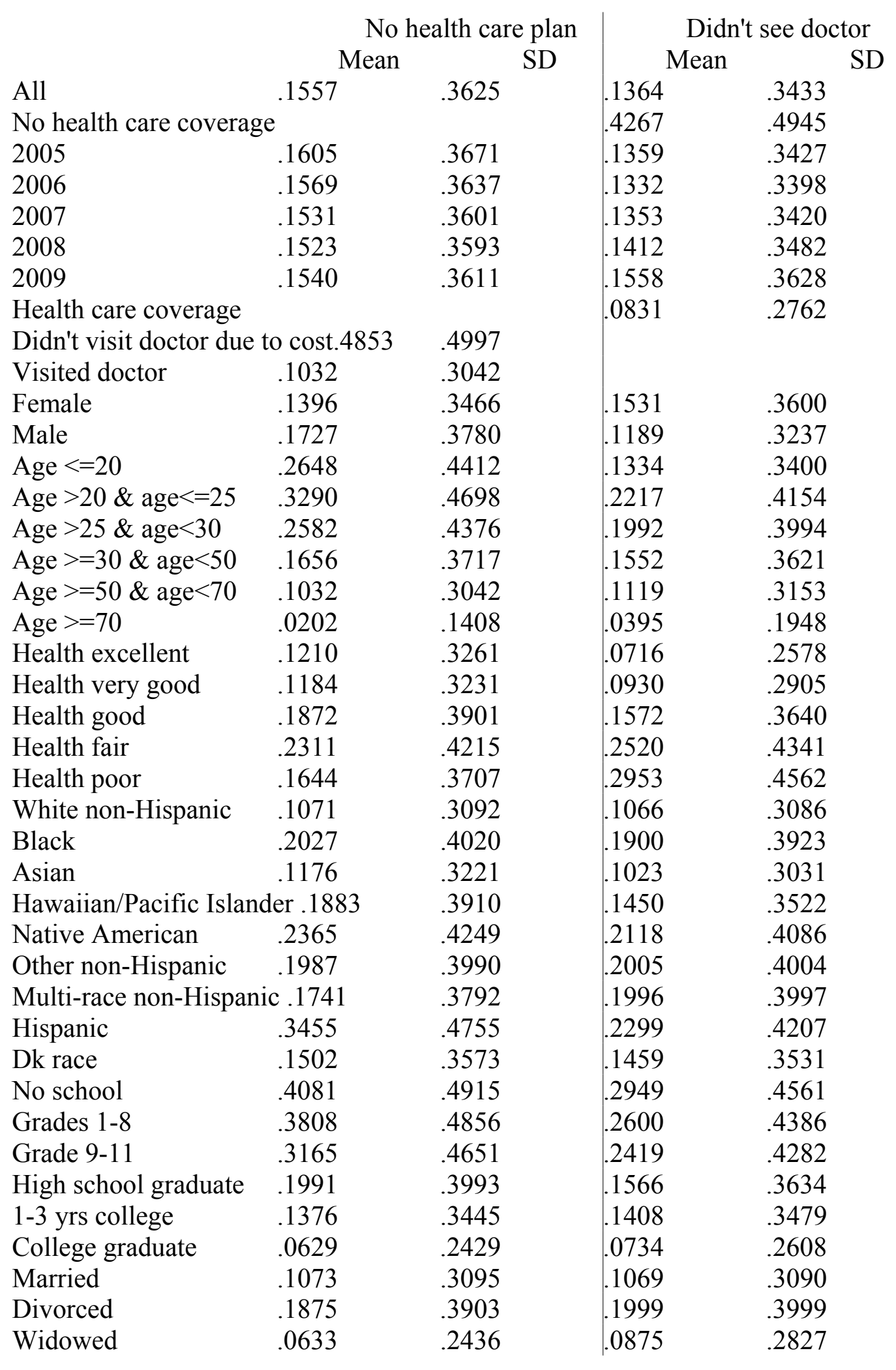




\begin{tabular}{|c|c|c|c|c|}
\hline Separated & .2951 & .4560 & .2853 & .4515 \\
\hline Single & .2702 & .4440 & .1742 & .3793 \\
\hline Unmarried couple & .3553 & .4786 & .2594 & .4383 \\
\hline$<\$ 10 \mathrm{k}$ & .3313 & .4707 & .3078 & .4616 \\
\hline$\$ 10$ and $<\$ 15 \mathrm{k}$ & .3157 & .4648 & .2927 & .4550 \\
\hline$\geq \$ 15 \&<\$ 20 k$ & .3359 & .4723 & .2777 & .4479 \\
\hline$\geq \$ 20-\$ 25$ & .2887 & .4531 & .2405 & .4274 \\
\hline$\geq \$ 25-\$ 35$ & .2132 & .4096 & .1826 & .3863 \\
\hline$\geq \$ 35-\$ 50$ & .1292 & .3354 & .1249 & .3306 \\
\hline$\geq \$ 50-\$ 75$ & .0699 & .2551 & .0771 & .2668 \\
\hline$>=\$ 75 \mathrm{k}$ & .0371 & .1891 & .0384 & .1923 \\
\hline Wage worker & .1384 & .3453 & .1223 & .3276 \\
\hline Self-employed & .2521 & .4342 & .1644 & .3706 \\
\hline Unemployed $>12 \mathrm{~m}$ & s.3819 & .4858 & .3155 & .4647 \\
\hline Unemployed $<12 \mathrm{n}$ & ns. 4579 & .4982 & .3106 & .4627 \\
\hline Homemaker & .2067 & .4049 & .1691 & .3748 \\
\hline Student & .1984 & .3988 & .1372 & .3440 \\
\hline Retired & .0316 & .1751 & .0465 & .2107 \\
\hline Disabled & .1484 & .3555 & .2799 & .4489 \\
\hline Labor force other & .2699 & .4439 & .1646 & .3709 \\
\hline Alabama* & .1595 & .3662 & .1623 & .3687 \\
\hline Alaska & .1677 & .3736 & .1450 & .3521 \\
\hline Arizona* & .1915 & .3935 & .1360 & .3428 \\
\hline Arkansas* & .1963 & .3972 & .1651 & .3713 \\
\hline California & .1700 & .3757 & .1442 & .3513 \\
\hline Colorado & .1675 & .3734 & .1319 & .3384 \\
\hline Connecticut & .0926 & .2899 & .0903 & .2866 \\
\hline Delaware & .0786 & .2692 & .0930 & .2905 \\
\hline District & .0900 & .2863 & .0996 & .2995 \\
\hline Florida* & .1922 & .3940 & .1516 & .3586 \\
\hline Georgia* & .1643 & .3706 & .1561 & .3629 \\
\hline Hawaii & .0711 & .2570 & .0683 & .2522 \\
\hline Idaho* & .1883 & .3910 & .1574 & .3642 \\
\hline Illinois & .1485 & .3557 & .1253 & .3311 \\
\hline Indiana & .1513 & .3583 & .1401 & .347 \\
\hline Iowa* & .1018 & .3024 & .0837 & .276 \\
\hline Kansas* & .1249 & .3306 & .1119 & .3152 \\
\hline Kentucky & .1623 & .3688 & .1696 & .3753 \\
\hline Louisiana* & .2137 & .4099 & .1763 & .381 \\
\hline Maine & .1156 & .3198 & .0981 & .297 \\
\hline Maryland & .1153 & .3195 & .1036 & .3047 \\
\hline Massachusetts & .0734 & .2608 & .0744 & .2624 \\
\hline Michigan & .1233 & .3288 & .1235 & .329 \\
\hline Minnesota & .0796 & .2706 & .0915 & .288 \\
\hline Mississippi* & .1954 & .3965 & .1892 & .391 \\
\hline Missouri & .1354 & .3421 & .1441 & .3512 \\
\hline
\end{tabular}




\begin{tabular}{|c|c|c|c|c|}
\hline Montana & .1805 & .3846 & .1270 & .3330 \\
\hline Nebraska* & .1311 & .3375 & .1015 & .3020 \\
\hline Nevada* & .2156 & .4112 & .1514 & .3584 \\
\hline New Hampshire & .1095 & .3123 & .0990 & .2987 \\
\hline New Jersey & .1402 & .3472 & .1291 & .3353 \\
\hline New Mexico & .2148 & .4107 & .1590 & .3657 \\
\hline New York & .1334 & .3400 & .1160 & .3202 \\
\hline North Carolina* & .1837 & .3872 & .1633 & .3696 \\
\hline North Dakota* & .1165 & .3209 & .0696 & .2545 \\
\hline Ohio & .1229 & .3283 & .1264 & .3324 \\
\hline Oklahoma* & .2010 & .4008 & .1747 & .3797 \\
\hline Oregon & .1657 & .3719 & .1422 & .3493 \\
\hline Pennsylvania & .1089 & .3116 & .1001 & .3001 \\
\hline Rhode Island & .1106 & .3136 & .1008 & .3010 \\
\hline South Carolina* & .1741 & .3792 & .1560 & .3629 \\
\hline South Dakota* & .1275 & .3335 & .0867 & .2815 \\
\hline Tennessee* & .1463 & .3535 & .1511 & .3581 \\
\hline Texas* & .2632 & .4404 & .1968 & .3976 \\
\hline Utah* & .1503 & .3574 & .1247 & .3304 \\
\hline Vermont & .1140 & .3178 & .1005 & .3007 \\
\hline Virginia* & .1095 & .3122 & .1097 & .3125 \\
\hline Washington & .1412 & .3483 & .1253 & .3310 \\
\hline West Virginia & .1662 & .3723 & .1769 & .3816 \\
\hline Wisconsin & .1005 & .3007 & .0913 & .2881 \\
\hline Wyoming* & .1685 & .3743 & .1265 & .3324 \\
\hline Guam* & .2172 & .4125 & .1894 & .3920 \\
\hline Puerto Rico & .0794 & .2704 & .1382 & .345 \\
\hline Virgin Islands & .2908 & .4541 & .1627 & .3691 \\
\hline Not RTW state & .1364 & .3433 & .1236 & .3291 \\
\hline RTW state & .1881 & .3908 & .1564 & .3632 \\
\hline
\end{tabular}

* =Right to Work Law State

Question \#1. Was there a time in the past 12 months when you needed to see a doctor but could not because of cost?

Question \#2. Do you have any kind of health care coverage, including health insurance, prepaid plans such as HMOs, or government plans such as Medicare? 
Table 4. Dprobit and probability of no health care coverage, 2005-2009

\begin{tabular}{|c|c|c|c|}
\hline & 1) & (2) & \\
\hline 06 & $-.0024(3.63)$ & (1.66) & $.0002(0.38)$ \\
\hline & $-.0026(4.16)$ & .0034 (6.47) & $.0027(3.88)$ \\
\hline 08 & $-.0060(9.30)$ & $.0006(1.27)$ & $.0010(1.54)$ \\
\hline 09 & $-.0013(0.19)$ & $.0030(0.51)$ & $.0053(0.85)$ \\
\hline & .0008 (10.09) & $.0046(59.19)$ & $.0046(40.96)$ \\
\hline $\mathrm{ge}^{2}$ & $-.00007(50.56)$ & $-.00007(87.91)$ & $-.00007(56.38)$ \\
\hline [ale & $.0129(27.26)$ & $.0191(45.57)$ & .0190 (39.99) \\
\hline lack & $.0649(66.30)$ & $.0092(12.85)$ & $.0095(10.92)$ \\
\hline sian & $-.0062(3.13)$ & $.000 s$ & $-.0002(0.11)$ \\
\hline awaiian/Pacific Islan & nder .0473 (9.20) & .0109 & $4.20)$ \\
\hline merican & $.1006(47.14)$ & $.0238(16.22)$ & $.0235(9.93)$ \\
\hline ther non-Hispanic & $.0626(19.72)$ & $.0215(8.92)$ & $.0217(8.72)$ \\
\hline Uulti-race non-Hispan & nic .0439 (22.33) & & (5.27) \\
\hline ispanic & $.1708(44.25)$ & .79) & $6.18)$ \\
\hline $\mathrm{k}$ race & .067 & 8) & $.58)$ \\
\hline laska & $.0026(0.82)$ & $.25)$ & $(4.59)$ \\
\hline rizo & -.002 & & .86) \\
\hline rka & .025 & & \\
\hline alifc & $-.03 \varepsilon$ & & $01)$ \\
\hline olor & -.018 & .00 & .00 \\
\hline icut & $-.0378(16.64)$ & $5(7.11)$ & $-.0132(5.36)$ \\
\hline$E c$ & -.04 & & -.02 \\
\hline & -.06 & & -.02 \\
\hline$U_{1}$ & $1.07)$ & .02 & 10.59) \\
\hline eoroja & .0009 (0.36) & $.0115(5.23)$ & $.0133(4.93)$ \\
\hline aw & -.051 & & 2.45) \\
\hline al & .020 & & .01 \\
\hline lin & $-.02 \varepsilon$ & -.00 & -.00 \\
\hline ndian & $-.0049(1.89)$ & $-.0017(0.84)$ & $-.0001(0.04)$ \\
\hline Iowa & $-.0323(12.99)$ & & $-.0190(8.56)$ \\
\hline ansa & -.023 & & -.00 \\
\hline en & .025 & & .01 \\
\hline Louis & $.0385(13.32)$ & $.0417(16.44)$ & $.0419(12.76)$ \\
\hline Maine & $-.0076(2.86)$ & $-.0106(5.07)$ & $-.0092(4.13)$ \\
\hline & -.036 & & $-.0079(3.86)$ \\
\hline ts & -.05 & & -.03 \\
\hline Mic & -.02 & -.01 & -.00 \\
\hline Minne & $-.0480(18.66)$ & $-.0262(11.83)$ & $-.0253(10.55)$ \\
\hline Mississippi & $.0158(5.90)$ & $.0073(3.44)$ & $.0110(4.02)$ \\
\hline Missouri & $-.0010(0.40)$ & & $-.0026(1.04)$ \\
\hline & & & $.0201(6.30)$ \\
\hline $\mathrm{Neb}$ & $-.0079(3.43)$ & $-.0060(3.21)$ & $-.0071(3.26)$ \\
\hline Nevada & $.0059(2.02)$ & $.0204(7.74)$ & $.0221(7.76)$ \\
\hline New Hampshire & $-.0137(5.40)$ & $-.0004(0.22)$ & $-.0009(0.38)$ \\
\hline
\end{tabular}




\begin{tabular}{|c|c|c|c|}
\hline New Jersey & -.0293 (13.93) & $-.0055(2.94)$ & $-.0045(1.95)$ \\
\hline New Mexico & $-.0010(0.40)$ & $.0086(3.97)$ & $.0090(3.33)$ \\
\hline New York & $-.0375(16.74)$ & $-.0212(11.28)$ & $-.0200(9.05)$ \\
\hline North Carolina & $-.0015(0.68)$ & $.0010(0.56)$ & $.0028(1.26)$ \\
\hline North Dakota & $-.0124(4.50)$ & $-.0067(3.00)$ & $-.0078(2.98)$ \\
\hline Ohio & $-.0180(7.89)$ & $-.0113(6.06)$ & $-.0089(3.75)$ \\
\hline Oklahoma & $.0228(8.80)$ & $.0157(7.41)$ & $.0160(6.39)$ \\
\hline Oregon & $.0021(0.82)$ & $.0008(0.40)$ & $.0034(1.40)$ \\
\hline Pennsylvania & $-.0175(8.12)$ & $-.0168(10.01)$ & $-.0156(7.51)$ \\
\hline Rhode Island & $-.0341(13.20)$ & $-.0183(8.38)$ & $-.0163(6.32)$ \\
\hline South Carolina & $.0083(3.41)$ & $.0106(5.19)$ & $.0140(5.16)$ \\
\hline South Dakota & $-.0050(1.97)$ & $-.0061(3.01)$ & $-.0073(2.93)$ \\
\hline Tennessee & $.0047(1.66)$ & $.0001(0.05)$ & $.0022(0.68)$ \\
\hline Texas & $.0262(10.34)$ & $.0367(16.18)$ & $.0382(14.04)$ \\
\hline Utah & $-.0179(7.02)$ & $-.0012(0.57)$ & $-.0024(1.02)$ \\
\hline Vermont & $-.0183(7.46)$ & $-.0140(7.15)$ & $-.0138(6.06)$ \\
\hline Virginia & $-.0273(11.12)$ & $-.0087(4.06)$ & $-.0096(3.85)$ \\
\hline Washington & $-.0128(6.25)$ & $-.0034(1.97)$ & $-.0017(0.83)$ \\
\hline West Virginia & $.0220(7.07)$ & $.0026(1.10)$ & $.0035(1.42)$ \\
\hline Wisconsin & $-.0184(7.43)$ & $-.0137(6.89)$ & $-.0126(5.34)$ \\
\hline Wyoming & $.0137(5.01)$ & $.0250(10.38)$ & $.0231(7.84)$ \\
\hline Guam & $.0210(2.79)$ & $-.0071(1.34)$ & \\
\hline Puerto Rico & $-.0827(49.79)$ & $-.0579(50.83)$ & $-.0565(30.65)$ \\
\hline Virgin Islands & $.0416(12.22)$ & $.0320(11.26)$ & \\
\hline Grades 1-8 & & $-.0071(1.81)$ & $-.0069(1.69)$ \\
\hline Grade 9-11 & & $-.0193(5.40)$ & $-.0188(5.08)$ \\
\hline High school graduate & & $-.0359(9.80)$ & $-.0352(9.22)$ \\
\hline $1-3$ yrs college & & $-.0453(13.10)$ & $-.0446(12.41)$ \\
\hline College graduate & & $-.0657(18.79)$ & $-.0649(17.88)$ \\
\hline Married & & $-.0244(38.20)$ & $-.0244(35.28)$ \\
\hline Divorced & & $.0056(7.95)$ & $.0056(7.59)$ \\
\hline Widowed & & $-.0109(12.37)$ & $-.0110(11.63)$ \\
\hline Separated & & $-.0029(2.64)$ & $-.0033(2.83)$ \\
\hline Unmarried couple & & $.0275(22.26)$ & $.0272(20.82)$ \\
\hline \# children & & $-.0027(14.39)$ & $-.0025(10.88)$ \\
\hline Self-employed & & $.1083(24.37)$ & $.1065(98.70)$ \\
\hline Unemployed $>12$ months & & $.0784(50.81)$ & $.0779(44.46)$ \\
\hline Unemployed $<12$ month & & $.1319(86.83)$ & $.1310(77.92)$ \\
\hline Homemaker & & $.0406(46.34)$ & $.0398(40.99)$ \\
\hline Student & & $-.0002(0.21)$ & $-.0006(0.54)$ \\
\hline Retired & & $-.0225(31.37)$ & $-.0223(27.76)$ \\
\hline Disabled & & $-.0341(55.37)$ & $-.0339(45.55)$ \\
\hline Labor force other & & $.0446(10.01)$ & $.0431(9.22)$ \\
\hline$\$ 10 \mathrm{k}$ and $<\$ 15 \mathrm{k}$ & & $.0063(6.31)$ & $.0059(5.62)$ \\
\hline$\geq \$ 15 \mathrm{k} \&<\$ 20 \mathrm{k}$ & & $.0044(4.74)$ & $.0045(4.60)$ \\
\hline$\geq \$ 20 \mathrm{k}-\$ 25 \mathrm{k}$ & & $-.0101(11.86)$ & $-.0100(10.70)$ \\
\hline
\end{tabular}


$\geq \$ 25 \mathrm{k}-\$ 35 \mathrm{k}$

$\geq \$ 35 \mathrm{k}-\$ 50 \mathrm{k}$

$\geq \$ 50 \mathrm{k}-\$ 75 \mathrm{k}$

$>=\$ 75 \mathrm{k}$

BMI

\# adults

Log state unemployment rate $\mathrm{N}$

Pseudo $\mathrm{R}^{2}$

$\begin{array}{cc}-.0332(44.95) & -.0327(37.20) \\ -.0551(84.68) & -.0546(68.75) \\ -.0709(16.94) & -.0703(94.23) \\ -.0953(46.29) & -.0945(16.43) \\ -.0005(18.80) & -.0005(17.45) \\ .0114(46.00) & .0114(42.26) \\ & -.0064(2.94) \\ 1,540,017 & 1,471,393 \\ .2415 & .2408\end{array}$

$1,460,086$ 
Table 5. Dprobit and probability that in the past 12 months when you needed to see a doctor but could not because of cost?

(3)

(4)

(5)

$\begin{array}{lccccc} & & & \text { Age } \geq 65 & \text { Age }<65 & \begin{array}{c}\text { All ages } \\ \text { Age }\end{array} \\ \text { Age }^{2} & .0034(39.95) & .0045(50.1) & -.0139(18.8) & .0080(38.94) & .0045(40.70) \\ \text { Male } & -.00005(69.87) & -.00007(73.8) & .0000(17.5) & -.0001(45.66) & -.0000(58.54) \\ \text { Black } & -.0330(66.29) & -.0208(44.05) & .0039(6.11) & -.0323(43.83) & -.0205(36.75) \\ \text { Asian } & .0645(63.47) & .0057(7.04) & .0184(14.82) & -.0007(0.65) & .0060(6.53) \\ \text { Hawaiian/Pacific Islander } .0587(10.47) & .0190(4.17) & .0415(3.90) & .0134(2.20) & .0154(3.27) \\ \text { Native American } & .0745(33.76) & .0050(3.07) & .0266(8.91) & -.0023(0.79) & .0048(2.21) \\ \text { Other non-Hispanic } & .0791(23.27) & .0360(12.59) & .0181(4.58) & .0431(11.15) & .0366(12.80) \\ \text { Multi-race non-Hispanic } & .0811(37.81) & .0318(18.19) & .0183(7.13) & .0390(13.43) & .0319(15.06) \\ \text { Hispanic } & .1000(86.52) & .0128(13.85) & .0222(13.84) & .0110(7.70) & .0126(11.15) \\ \text { Dk race } & .0731(24.47) & .0330(12.67) & .0179(7.30) & .0367(9.54) & .0325(12.47) \\ \text { 2006 } & -.0039(5.59) & -.0010(1.61) & -.0025(2.81) & .0006(0.58) & -.0003(0.46) \\ \text { 2007 } & -.0026(3.76) & .0033(5.27) & -.0019(2.23) & .0073(7.13) & .0043(5.70) \\ \text { 2008 } & .0003(0.51) & .0063(10.03) & -.0009(1.24) & .0096(9.40) & .0058(7.93) \\ \text { 2009 } & .0120(1.56) & .0224(3.07) & .0084(0.45) & .0233(3.66) & .0192(2.66) \\ \text { Grades 1-8 } & & -.0145(3.22) & -.0028(0.68) & -.0219(3.06) & -.0146(2.99) \\ \text { Grade 9-11 } & & -.0233(5.44) & -.0098(2.58) & -.0222(3.14) & -.0233(5.01) \\ \text { High school graduate } & & -.0412(9.42) & -.0193(4.88) & -.0442(6.24) & -.0410(8.62) \\ \text { 1-3 yrs college } & & -.0357(8.20) & -.0170(4.61) & -.0387(5.43) & -.0356(7.54) \\ \text { College graduate } & & -.0511(11.70) & -.0201(5.45) & -.0609(8.44) & -.0510(10.71) \\ \text { Married } & & .0056(7.42) & .0027(1.71) & .0053(4.95) & .0057(6.88) \\ \text { Divorced } & & .0283(30.94) & .0099(5.85) & .0333(26.66) & .0284(29.67) \\ \text { Widowed } & & .0082(7.51) & .0035(2.32) & .0160(8.75) & .0084(7.41) \\ \text { Separated } & & .0336(22.19) & .0171(5.44) & .0364(18.19) & .0336(21.29) \\ \text { Unmarried couple } & & .0499(31.76) & .0223(4.38) & .0602(28.71) & .0498(29.23) \\ \text { \# children } & & .0024(11.0) & .0060(8.96) & .0015(4.64) & .0025(9.91) \\ \text { Self-employed } & & .0733(51.22) & .0010(0.70) & .0611(49.34) & .0455(47.22) \\ \text { Unemployed>12 months } & & & .0343(9.70) & .0883(39.15) & .0731(41.00)\end{array}$




\section{Unemployed $<12$ months \\ Homemaker \\ Student \\ Retired \\ Disabled \\ Labor force other \\ $\$ 10 \mathrm{k}$ and $<\$ 15 \mathrm{k}$ \\ $\geq \$ 15 \mathrm{k} \mathrm{\&}<\$ 20 \mathrm{k}$ \\ $\geq \$ 20 \mathrm{k}-\$ 25 \mathrm{k}$ \\ $>\$ 25 \mathrm{k}-\$ 35 \mathrm{k}$ \\ $\geq \$ 35 \mathrm{k}-\$ 50 \mathrm{k}$ \\ $\geq \$ 50 \mathrm{k}-\$ 75 \mathrm{k}$ \\ $>=\$ 75 \mathrm{k}$ \\ BMI \\ \# adults}

Log state unemployment rate
Pseudo $\mathrm{R}^{2}$

$.0795(51.82)$
$.0053(6.07)$
$-.0087(6.09)$
$-.0260(32.24)$
$.0289(31.17)$
$.0242(4.90)$
$.0105(9.12)$
$-.0005(0.50)$
$-.0151(15.33)$
$-.0406(46.45)$
$-.0643(80.66)$
$-.0842(12.40)$
$-.1165(148.70)$
$.0007(20.94)$
$.0086(28.76)$

$.0205(4.81)$
$-.0040(3.19)$
$.0080(0.97)$
$-.0061(6.13)$
$.0308(18.46)$
$.0027(0.54)$
$.0014(1.34)$
$-.0090(8.62)$
$-.0164(16.63)$
$-.0248(26.29)$
$-.0308(33.08)$
$-.0321(32.77)$
$-.0340(34.26)$
$.0001(3.4)$
$.0039(7.51)$
$.0022(0.75)$

$1,540,269$

.1646

$$
\begin{array}{ll}
.0971(50.37) & .0793(50.52) \\
.0147(11.57) & .0052(5.76) \\
-.0061(3.12) & -.0088(5.80) \\
-.0284(19.65) & -.0261(31.97) \\
.0284(21.88) & .0286(28.49) \\
.0438(6.17) & .0237(4.96) \\
.0188(11.36) & .0106(9.30) \\
.0089(5.73) & -.0004(0.38) \\
-.0109(7.15) & -.0149(14.26) \\
-.0482(35.29) & -.0403(42.20) \\
-.0831(66.29) & -.0640(71.66) \\
-.1142(93.97) & -.0839(99.13) \\
-.1661(23.28) & -.1161(28.80) \\
.0009(19.73) & .0007(19.96) \\
.0114(27.51) & .0087(28.20) \\
.0111(3.48) & .0079(3.33) \\
29 & 1,053,940 \\
.1528 & .1651
\end{array}
$$$$
1,471,565 \quad 406,329
$$$$
.0890 \quad .1528
$$

Source: Behavioral Risk Factor Surveillance System, 2005-2008.

Notes; excluded categories white, wage worker $<$ annual income $<\$ 10 \mathrm{k}$, single., no schooling and 2005. All equations also include 11 month dummies. State unemployment rate is measure at the month*state*year level. Standard errors are clustered at month*state*year. All equations include a full set of state dummies. T-statistics in parentheses. 
Table 6. Life satisfaction equations, 2005-2009

(1)

(2)

(3)

Ordered logit Ordered logit Ordered logit OLS

(4)

$\begin{array}{lclll}\text { Couldn't afford a doctor-.7304 (122.89) } & -.7282(118.27) & & -.2116(132.56) \\ \text { No health care plan } & & -.0074(1.18) & -.2013(33.16) & \\ 2006 & .0339(6.63) & .0341(6.65) & .0344(6.75) & .0099(7.03) \\ 2007 & -.0855(17.26) & -.0853(17.19) & -.0876(17.71) & -.0337(24.59) \\ 2008 & -.0379(7.66) & -.0377(7.62) & -.0432(8.74) & -.0195(14.29) \\ 2009 & -.0897(1.58) & -.0880(1.54) & -.1031(1.81) & -.0340(2.16) \\ \text { Black } & .0959(13.35) & .0962(13.38) & .0883(12.32) & .0310(15.69) \\ \text { Asian } & -.3466(23.56) & -.3462(23.51) & -.3485(23.75) & -.0849(20.57) \\ \text { Hawaiian/Pacific Islander } .0686(1.83) & .0733(1.94) & .0605(1.61) & .0195(1.88) \\ \text { Native American } & .1344(8.95) & .1367(9.08) & .1432(9.54) & .0361(8.76) \\ \text { Other non-Hispanic } & -.0908(4.05) & -.0903(4.02) & -.1136(5.08) & -.0264(4.28) \\ \text { Multi-race non-Hispanic }-.0798(5.79) & -.0793(5.75) & -.1020(7.42) & -.0237(6.28) \\ \text { Hispanic } & .0946(11.57) & .0959(11.67) & .0870(10.64) & .0298(13.19) \\ \text { BMI } & -.0169(54.99) & -.0169(54.91) & -.0180(58.44) & -.0045(53.58) \\ \text { Age } & -.0150(21.74) & -.0149(21.53) & -.0156(22.74) & -.0045(24.01) \\ \text { Age } & .00017(26.17) & .0001(25.97) & .0001(28.73) & .00005(28.85) \\ \text { Male } & -.1217(32.22) & -.1220(32.21) & -.0973(25.82) & -.0332(31.82) \\ \text { Grades 1-8 } & -.0957(1.99) & -.0933(1.93) & -.0719(1.50) & -.0239(1.81) \\ \text { Grade 9-11 } & -.0525(1.10) & -.0505(1.06) & -.0254(0.54) & -.0136(1.04) \\ \text { High school graduate } & -.0176(0.37) & -.0161(0.34) & .0182(0.39) & -.0047(0.37) \\ \text { 1-3 yrs college } & -.0183(0.39) & -.0168(0.35) & .0072(0.15) & -.0080(0.61) \\ \text { College graduate } & .1301(2.74) & .1317(2.77) & .1570(3.32) & .0294(2.26) \\ \text { Married } & .5884(90.47) & .5897(90.45) & .5706(87.82) & .1641(91.15) \\ \text { Divorced } & .0458(6.21) & .0469(6.35) & .0245(3.32) & .0107(5.29) \\ \text { Widowed } & .0994(11.96) & .0997(11.98) & .0923(11.13) & .0301(13.07) \\ \text { Separated } & -.2141(16.25) & -.2122(16.10) & -.2478(18.82) & -.0628(17.58) \\ \text { Unmarried couple } & .2285(18.66) & .2316(18.88) & .1962(16.05) & .0659(19.39) \\ \text { \# children } & -.0160(8.20) & -.0162(8.29) & -.0210(10.81) & -.0035(6.58)\end{array}$




\begin{tabular}{|c|c|c|c|c|}
\hline Self-employed & $.1437(22.56)$ & $.1441(22.48)$ & $.1307(20.48)$ & $.0370(21.04)$ \\
\hline \multicolumn{2}{|c|}{ Unemployed $>12$ months-. 6290 (43.54) } & $-.6283(43.35)$ & $-.6726(46.42)$ & $-.1901(49.42)$ \\
\hline \multicolumn{2}{|c|}{ Unemployed $<12$ months-.4985 (39.94) } & $-.4989(39.72)$ & $-.5377(42.80)$ & $-.1479(43.96)$ \\
\hline Homemaker & $.0971(13.59)$ & $.0979(13.68)$ & $.0990(13.90)$ & $.0210(10.70)$ \\
\hline Student & $.1867(13.80)$ & $.1857(13.64)$ & $.1912(14.09)$ & 2.75) \\
\hline Retired & $.1773(29.54)$ & $.1769(29.44)$ & $.1882(31.40)$ & $.0417(25.12)$ \\
\hline Disabled & $-.8306(95.90)$ & $-.8324(95$. & $-.8741(100.81)$ & $-.2493(109.69$ \\
\hline orce other & -.070 & -.072 & $-.0809(1.97)$ & $-.0286(-2.53)$ \\
\hline$\$ 10$ & .056 & .05 & $.0509(4.48)$ & 64) \\
\hline$\geq \$ 1$ & .1391 & .139 & $.1440(13.30)$ & .77) \\
\hline$\geq \$ 20 \mathrm{k}$ & .202 & .201 & $.2195(20.86)$ & $41)$ \\
\hline$\geq \$ 2$ & .290 & .29 & $.3305(32.18)$ & 32) \\
\hline$\geq \$ 3$ & .4167 & .4160 & $.4780(46.60)$ & 16) \\
\hline$-\$ 75 k$ & .5745 & .573 & $.6557(62.37)$ & $30)$ \\
\hline$>=\$$ & .854 & .85 & $.9535(89.62)$ & $85)$ \\
\hline$\# \mathrm{ad}$ & .0224 & .022 & $.0178(6.72)$ & 24) \\
\hline Non & .3943 & .393 & $-.1265(13.49)$ & $(13.87)$ \\
\hline $\mathrm{Sm}$ & $.11 \xi$ & .11 & $.2179(24.62)$ & .05 \\
\hline Gav & .319 & .318 & $.3021(35.35)$ & .0775 \\
\hline 30 days & $.3826(91.32)$ & $.3826(91.20)$ & $.3824(91.40)$ & $.1112(95.96)$ \\
\hline Cut $1 /$ constant & -5.0998 & -5.0974 & -5.0405 & 3.3353 \\
\hline Cut 2 & -2.8552 & -2.8521 & -2.8092 & \\
\hline Cut 3 & .5900 & .5934 & .5983 & \\
\hline \multicolumn{5}{|l|}{ Cut 4} \\
\hline $\mathrm{N}$ & \multicolumn{2}{|l|}{1404029} & \multirow{2}{*}{$\begin{array}{c}1,401,253 \\
.0731\end{array}$} & נים \\
\hline Pseudo/Adjusted $\mathrm{R}^{2}$ & .0788 & .0789 & & .1382 \\
\hline
\end{tabular}

$1,404,029$

Source: Behavioral Risk Factor Surveillance System, 2005-2008.

Notes; excluded categories white, wage worker, annual income $<\$ 10 \mathrm{k}$, single, no schooling, smokes every day and $2005 . \quad \mathrm{T}$-statistics in parentheses. All equations also include 11 month dummies and two additional income variables for DK and Not answered, a schooling level $\mathrm{dk}$ and race $\mathrm{dk}$. All equations include a full set of state dummies.

In general, how satisfied are you with your life? - very dissatisfied, dissatisfied, satisfied or very satisfied? T-statistics in parentheses. 
Table 7. Life satisfaction ordered logits by various income levels and coverage $<\$ 20 \mathrm{k} \quad \$ 20 \mathrm{k} \&<\$ 50 \mathrm{k} \quad \geq \$ 50 \mathrm{k} \&<\$ 75 \mathrm{k} \quad \geq \$ 75 \mathrm{k}$

$\begin{array}{lcc}\text { Couldn't afford a doctor-.6594 (61.71) } & -.7168(77.22) \\ 2006 & .0211(1.74) & .0360(4.21) \\ 2007 & -.1551(12.93) & -.0773(9.29) \\ 2008 & -.0855(7.18) & -.0289(3.46) \\ 2009 & -.3034(1.81) & .0655(0.62) \\ \text { Black } & .2593(18.29) & .0823(7.00) \\ \text { Asian } & -.2511(5.54) & -.2722(9.74) \\ \text { Hawaiian/Pacific Islander .2156(2.34) } & .0527(0.87) \\ \text { Native American } & .1751(6.41) & .1396(5.74) \\ \text { Other non-Hispanic } & .0166(0.33) & -.0607(1.62) \\ \text { Multi-race non-Hispanic -.0016(0.06) } & -.0638(2.79) \\ \text { Hispanic } & .1935(11.52) & .1126(8.50) \\ \text { BMI } & -.0103(16.17) & -.0164(31.68) \\ \text { Age } & -.0186(11.93) & -.0172(15.31) \\ \text { Age } & .0002(17.01) & .0001(18.24) \\ \text { Male } & -.1259(12.64) & -.1379(21.58) \\ \text { Grades 1-8 } & -.0125(0.17) & -.1607(1.69) \\ \text { Grade 9-11 } & .0216(0.29) & -.0905(0.96) \\ \text { High school graduate } & .0430(0.59) & -.0511(0.55) \\ \text { 1-3 yrs college } & -.0086(0.12) & -.0552(0.59) \\ \text { College graduate } & .0551(0.74) & .0546(0.58) \\ \text { Married } & .4448(28.86) & .5747(54.67) \\ \text { Divorced } & -.0075(0.51) & .0750(6.47) \\ \text { Widowed } & .1290(7.81) & .1200(9.05) \\ \text { Separated } & -.1155(5.28) & -.2385(10.82) \\ \text { Unmarried couple } & .1685(6.10) & .2225(11.01) \\ \text { \# children } & -.0135(2.69) & -.0179(5.33) \\ & & \end{array}$

$$
\begin{aligned}
& -.7341(59.83) \\
& .0263(2.83) \\
& -.0707(7.86) \\
& -.0430(4.76) \\
& -.1328(1.29) \\
& -.0042(0.30) \\
& -.3626(13.17) \\
& -.0000(0.00) \\
& .1444(4.75) \\
& -.1426(3.28) \\
& -.1014(3.97) \\
& .0782(4.75) \\
& -.0193(33.08) \\
& -.0231(17.07) \\
& .0002(18.91) \\
& -.1232(18.36) \\
& -.2089(1.40) \\
& -.1111(0.76) \\
& -.0354(0.25) \\
& -.0322(0.22) \\
& .0867(0.60) \\
& .6008(50.74) \\
& .0873(6.40) \\
& .0137(0.80) \\
& -.3480(12.02) \\
& .2323(10.08) \\
& -.0216(6.24) \\
&
\end{aligned}
$$

$\geq \$ 75 \mathrm{k} \&$ health very good or excellent

With health care coverage

$\begin{array}{lll}-.8011(37.06) & -.6978(24.51) & -.7303(98.45) \\ .0366(3.14) & .0563(3.98) & .0355(6.51) \\ -.0781(7.06) & -.0589(4.38) & -.0791(15.00) \\ -.0298(2.72) & -.0152(1.15) & -.0327(6.22) \\ -.0795(0.79) & -.0909(0.73) & -.1062(1.75) \\ -.1187(5.87) & -.1265(4.85) & .0901(11.51) \\ -.4112(16.28) & -.3245(10.32) & -.3499(22.68) \\ .0882(1.02) & -.0385(0.35) & .0888(2.15) \\ .1043(2.22) & .2099(3.23) & .1228(7.11) \\ -.1443(2.77) & -.2041(3.24) & -.1073(4.40) \\ -.0962(2.87) & -.0480(1.11) & -.0857(5.76) \\ .0192(0.85) & .0468(1.64) & .0798(8.48) \\ -.0250(32.37) & -.0100(9.25) & -.0175(52.88) \\ -.0184(9.36) & -.0307(11.98) & -.0141(18.78) \\ .0002(10.67) & .0003(14.02) & .0001(23.01) \\ -.0904(11.24) & -.0854(8.61) & -.1168(29.06) \\ -.2457(1.17) & -.2971(1.00) & -.0397(0.71) \\ -.0238(0.12) & -.2732(0.99) & .0056(0.11) \\ .0103(0.05) & -.2433(0.90) & .0525(0.95) \\ .0312(0.16) & -.2300(0.85) & .0606(1.10) \\ .1899(0.97) & -.0750(0.28) & .2118(3.84) \\ .6794(39.89) & .6694(33.00) & .5839(81.59) \\ .1398(6.29) & .0960(3.62) & .0420(5.19) \\ -.0519(1.72) & -.1481(3.87) & .0934(10.53) \\ -.5333(11.84) & -.5645(10.55) & -.2402(16.18) \\ .3257(11.63) & .3050(9.21) & .2264(15.97) \\ -.0171(4.32) & -.0142(3.01) & -.0227(10.60)\end{array}$




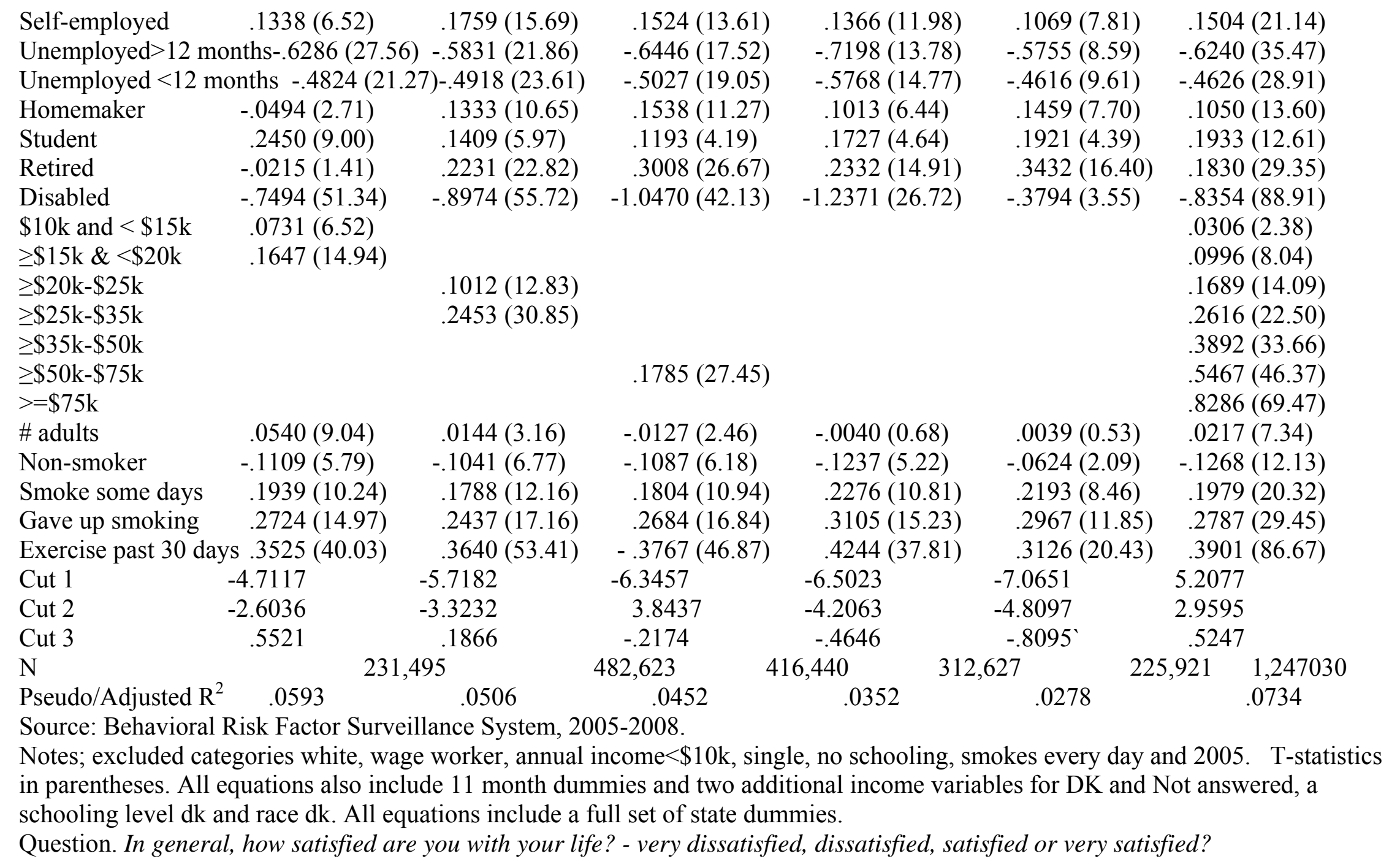


Table 8. Happiness, poor mental health and depression \#days mental health Depressed not good

OLS

Couldn't afford a doctor 3.0229 (152.70)

Age

$\mathrm{Age}^{2}$ $.0181(7.59)$

$-.0006(27.30)$

$.0074(2.43)$

Ordered logit

\# days 'down

Male

$-.9065(69.70)$

$-.0001(6.78)$

$-.9058(37.05)$

$-.1521(8.90)$

Black

$-.7104(13.92)$

$-.1121(3.95)$

Asian

$.3313(5.86)$

Hawaiian/Pacific Islander - -3078 (2.39)

Native American

$-.0434(0.85)$

$.1963(1.32)$

Other non-Hispanic

$.2489(3.26)$

Multi-race non-Hispanic $.6039(12.74)$

$.0168(0.30)$

$.1060(1.12)$

Hispanic

$-.8655(30.95)$

$.1375(2.81)$

BMI

$.0506(47.92)$

$.1655(4.78)$

Grades 1-8

$.1292(0.79)$

$.0102(8.38)$

Grade 9-11

$.2334(1.44)$

$-.1589(0.90)$

High school graduate

$.0231(0.14)$

$-.2798(1.60)$

1-3 yrs college

.2957 (1.84)

$-.5281(3.04)$

College graduate

$.0963(0.60)$

$-.6031(3.47)$

Married

$-.2100(9.38)$

.4341 (17.12)

$-.6862(3.94)$

Divorced

$.1600(5.56)$

$-.2347(8.65)$

$.0678(2.31)$

Widowed

$1.8324(41.51)$

$.0634(1.84)$

Separated

.2017 (4.76)

$.2795(6.06)$

Unmarried couple

$.0102(1.52)$

$.0289(0.60)$

\# children

-.0385 (1.76)

$-.0058(0.69)$

Self-employed

$.0733(2.39)$

Unemployed $>12$ months 2.9567 (62.15) .7484 (15.33)

Unemployed $<12$ months 1.8577 (44.58) $.4793(10.74)$

Homemaker

$.3616(14.67)$

Student

$.6539(13.92)$

$.1706(5.56)$

Retired

$.4959(23.87)$

$.1613(3.05)$

Disabled

$6.3700(226.26)$

$1408(5.09)$

$\$ 10 \mathrm{k}$ and $<\$ 15 \mathrm{k}$

$-.7732(20.32)$

$\geq \$ 15 \mathrm{k} \&<\$ 20 \mathrm{k}$

$\geq \$ 20 \mathrm{k}-\$ 25 \mathrm{k}$

$-1.1133(30.57)$

1.2157 (44.34)

$-.2038(5.55)$

$-.2732(7.58)$

-1.2797 (36.11)

$-.3234(8.89)$

$-1.5348(44.32)$

$-.4154(11.54)$

$-1.6265(47.06)$

$-.5472(14.95)$

$-1.7518(49.42)$

$-.6563(16.90)$

$\geq \$ 50 \mathrm{k}-\$ 75 \mathrm{k}$

$>=\$ 75 \mathrm{k}$

$-1.9800(50.77)$

$-.8198(20.63)$

\# adults

$-.0547(6.01)$

$-.0161(1.50)$

$-1.8071(95.29)$

-.4109 (19.09)

Non-smoker

$-.6391(19.90)$

$-.1050(2.94)$

$-1.3819(67.94)$

$-.3442(14.61)$

$-.3902(22.96)$

depressed or hopeless'

OLS

1.3057 (66.51)

$.0142(5.97)$

$-.0002(11.45)$

$-.2234(17.05)$

$-.1743(7.24)$

$-.1713(3.82)$

$-.0395(0.33)$

$.0028(0.06)$

$.0014(0.02)$

.1554 ( 3.87$)$

$-.0119(0.42)$

$.0200(18.96)$

$-.0416(0.25)$

$.0371(0.22)$

$-.1972(1.20)$

$-.1820(1.10)$

$-.1957(1.18)$

$-.1986(8.87)$

.1267 (4.99)

$.0412(1.41)$

$.6769(15.28)$

$-.0500(1.18)$

$-.0149(-2.27)$

$-.0346(-1.61)$

$1.1946(25.00)$

1.0518 (24.65)

$.2121(8.58)$

$.0451(0.98)$

$.2105(10.01)$

$2.5554(90.56)$

$-.2337(-6.36)$

$-.5266(14.89)$

$-.5879(16.90)$

$-.7722(22.92)$

$-.8612(25.56)$

-.8901 (25.72)

$-.9496(27.13)$

$-.0157(1.75)$

$-.2125(6.57)$

-.5975 (29.26)

-.6847 (36.13)

-.5614 (38.66) 
Figure 1. Health status and being unable to afford to visit a doctor

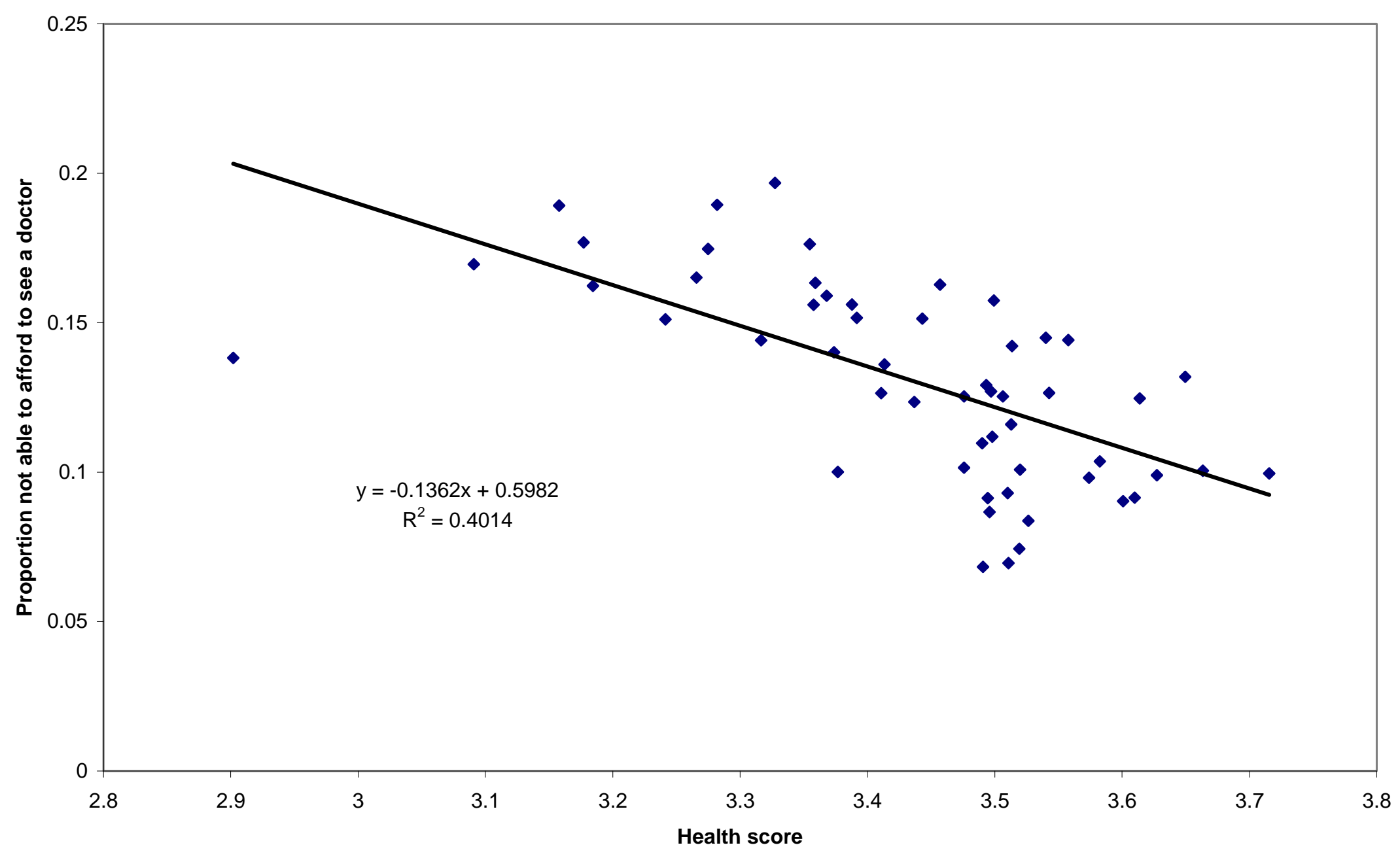


Figure 2. Fetal mortality rates and being unable to afford to visit a doctor

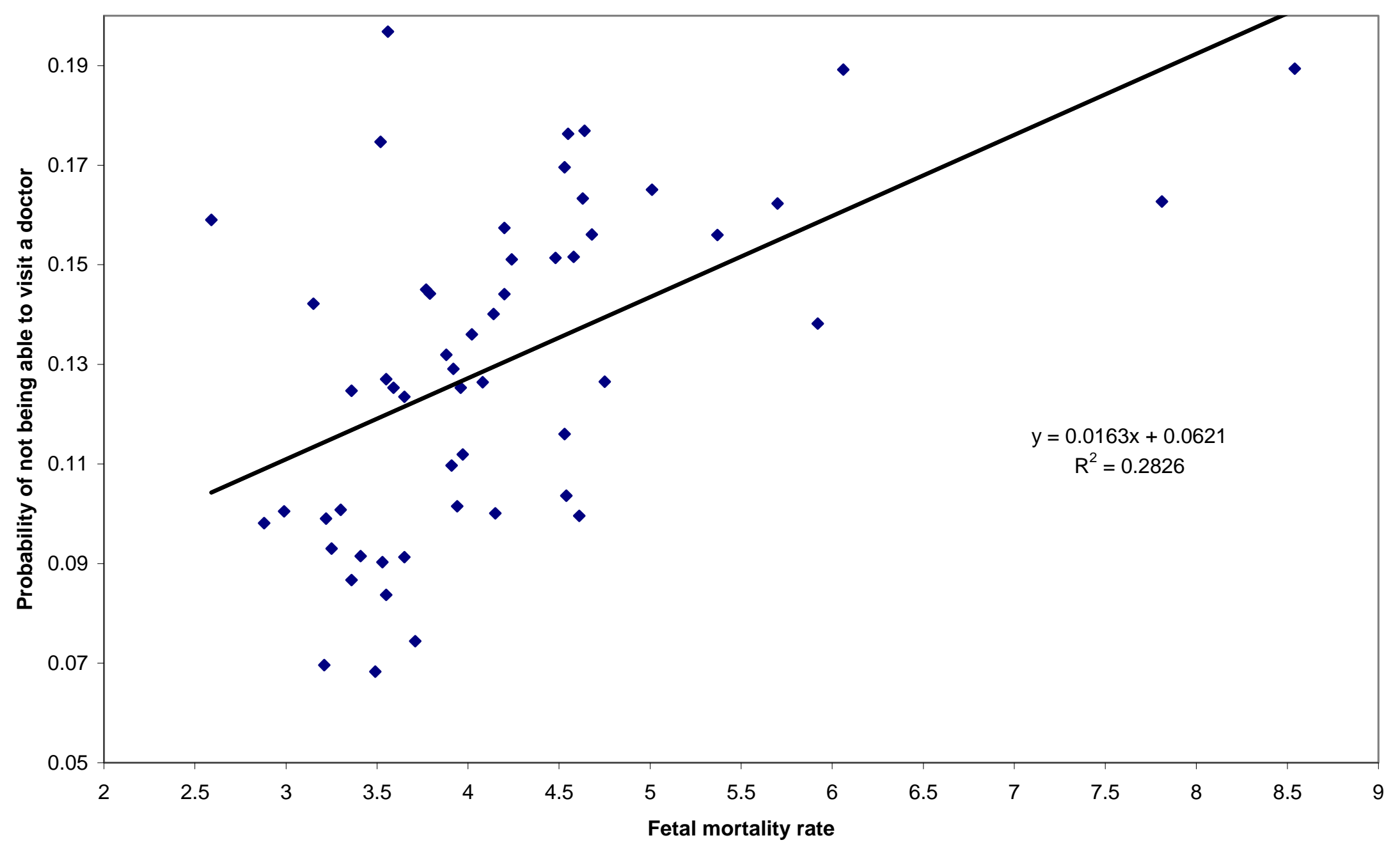


Figure 3. Intentional self-harm and being unable to afford a doctor

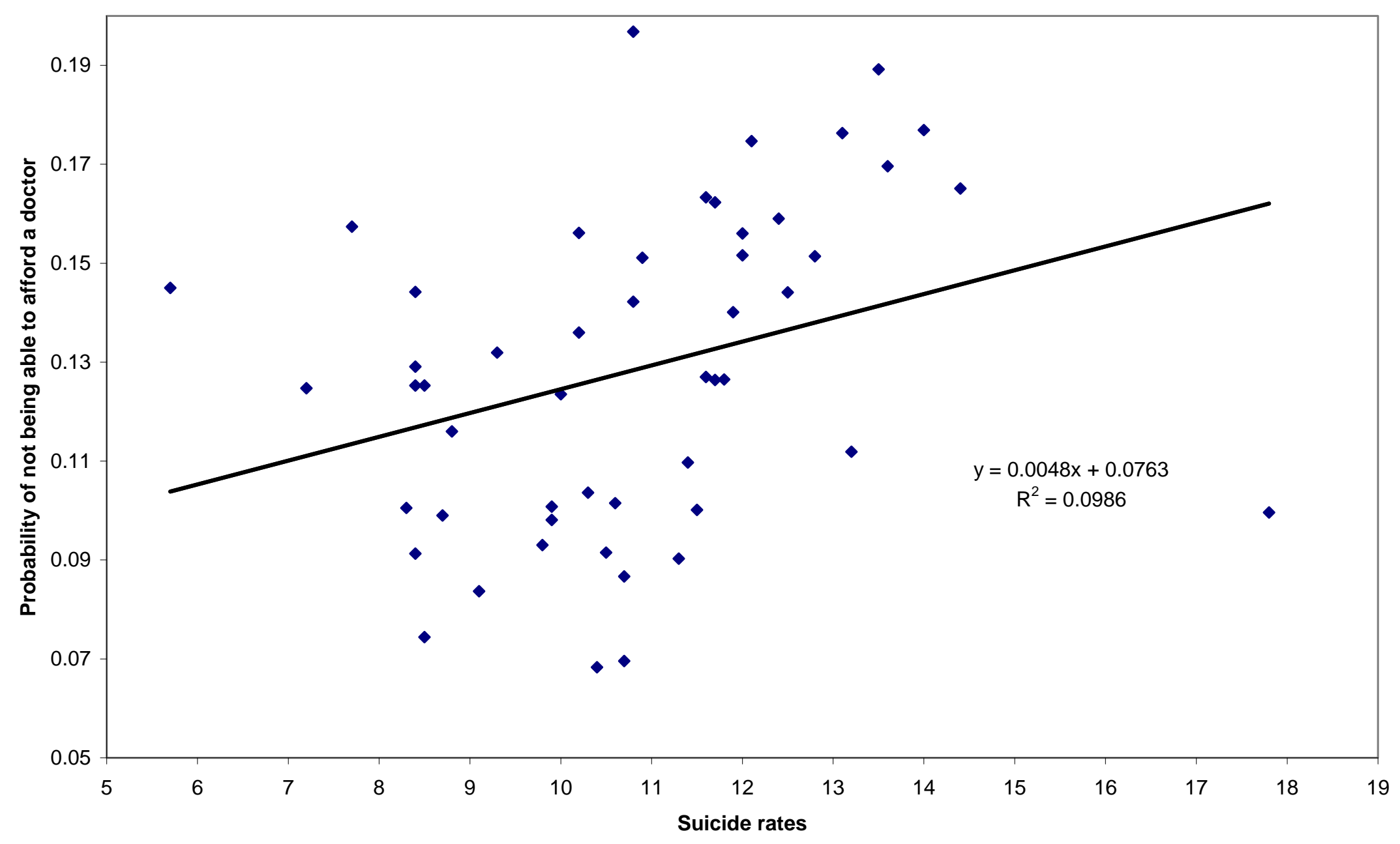

